\title{
Linguistic Intelligence in Learning to Write Explanation Text
}

\author{
$1^{\text {st }}$ Arni $^{1}, 2^{\text {nd }}$ Yeti Mulyati $^{2}, 3^{\text {rd }}$ Andoyo Sastromiharjo ${ }^{2}, 4^{\text {th }}$ Nuny Sulistiany Idris ${ }^{2}$ \\ \{ardini_47@yahoo.co.id ${ }^{1}$, yetimulyati@upi.edu ${ }^{2}$,andoyo@upi.edu ${ }^{3}$, nuny@upi.edu ${ }^{4}$ \}
}

Student of the Doctoral of Indonesian Language Education, Indonesian Universit y of Education,Bandung Indonesia ${ }^{1}$, Editor in the Doctoral of Indonesian Language Education, Indonesian University of Education, Bandung Indonesia ${ }^{2}$.

\begin{abstract}
This study purpose to describe the process of learning Indonesian, that is, students are required to be smart, creative, skilled and independent in understanding and applying the concepts learned in writing explanatory text material. So in the learning process, linguistic intelligence can improve the writing skills of explanatory texts in junior high schools by developing words / terms. The type of research used by researchers is descriptive analysis. Dat a collection techniques used observation, interviews, and documentation. Based on data obtained from three Indonesian language teachers and 96 students the level of linguistic intelligence of students in writing explanatory texts has increased. Students' linguistic intelligence is written in an explanatory text. The results of this study indicate that the factors that affect students' linguistic intelligence consist of factors from within and outside of students. Factors originating from within students include physical conditions, emotional conditions, and learning styles. While factors that come from outside the student self are supporting school programs.
\end{abstract}

Keywords: Linguistic intelligence, Learning, writing, explanatory text.

\section{Introduction}

Indonesian language learning activities in writing skills is one part of education as a conscious and planned effort. In Indonesian language learning activities, students are required to be smart, creative, skilled and independent in understanding and applying the concepts learned. Indonesian is one of the subjects strived to achieve educational goals through a learning atmosphere and a good learning process.

Writing skills must be based on linguistic intelligence to develop ideas in each student's ability problem. Learning to write with linguis tic intelligence, means the teacher tries to empower students' minds, invites students to think using their minds consciously in solving problems or solving application problems such as writing texts. For this reas on teachers should be able to choose and implement a more effective learning strategy to be presented in accordance with the form of the material to be delivered in improving writing skills that have linguistic intelligence. One effort that can be done is to change the conventional learning that is still used by some teachers to learning with constructivis m approach.

Linguistic intelligence is one element of compound intelligence. In daily activities linguistic intelligence is one of the important intelligences, because linguistic intelligence is related to oral and 
written abilities [2]. Linguistic intelligence is the ability of learners to use words effectively, both verbally and in written form [7]. Linguistic intelligence is the ability to use words effectively [1].

Basically all students from birth have all kinds of intelligence, but only one or two kinds of intelligence develop better. The development of student intelligencecan be influenced by genetic and environmental factors, so that each student has a different intelligence.

Writing is a series of results from thoughts outlined in written form. Writing or composing is an activity of capturing ideas in writing. Writing is one aspect of the four language skills. Writing activity is a way for people to express or formulate ideas, ideas, or thoughts in the form of language and written variety that can be understood, both by the author and others.

Writing skills are a form of language skill that is very important for students. Therefore, learning to write has a very strategic position in education and teaching. The activity of writing is a manifestation of the ability and language skills most recently mastered by language learners after the ability to listen, speak, and read [3].

Based on the facts that occur in the field can be illustrated that learning to write is still far from ideal conditions. Based on the condition of students in Kubu Raya Regency, which consists of five schools, there is still a lot less in writing due to geographical conditions that are far from educational facilities such as reading books, as well as the conditions of family livelihood.

Students still experience difficulties in various types of texts, es pecially text with a factual genre such as explanatory texts. Difficulties of students are caused by the following problems. 1) Difficulties in determining the topic of writing., 2) Difficulties in pouring thoughts and ideas into a text in accordance with the correct structure and systematic., 3) Do not understand well the purpose, function, and social context that underlies a text., 4 ) The low ability to think logically is critical, so the resulting text does not have a clear line of thinking., 5) The linguistic ability is also very lacking because it is still influenced by the mother tongue (area) which is very thick, and fosters an attitude of reading and writing to explore ideas, build relationship, analogy, while writing is needed to construct the results of the interpretation of an information and arrange conclusions in the form of a text by students. he condition of students' ability in writing explanatory texts is still below the school KKM standard, with an average grade of 65-68, while for the KKM standard an average of 75. Problems found in learning to write, become a big challenge for Indonesian lan guage teachers to be able to teach quality writing skills. For this reason, selection of approaches, models and methods of learning to write that are appropriate, interesting and innovative is needed.

Linguistic intelligence in writing explanatory texts is carried out with the following considerations: low student interest in learning to write; most students find it difficult to develop ideas and knowledge about linguistics, es pecially writing and reading, this is because the school is far from the city center because of the geographical location that is cros sed by land and water; students' ability to recognize terms is lacking due to the limitation of their linguis tic intelligence which is influenced by mother tongue; fifth, the potential that already exists in the self can be interpreted as a linguistic intelligence that has been possessed by students that can be used and optimized in writing explanatory text activities by paying attention to diction, word form, and terms used; sixth, most teachers have not been able to realize and utilize a linguistic intelligence that students have for the development of learning to write explanatory texts. This research was conducted in five schools in the Dis trict of Kubu Raya, West Kalimantan, in the VIII grade junior high school.

Home of the explanation above is the ability of students in accordance with linguistic intelligence in writing explanatory texts, because in constructing an interpretation in an information, students must first have the ability to recognize words and terms and good reasoning power. This research was conducted to foster students' linguistic intelligence at the junior high school level with the aim of fostering the attitude of linguistic intelligence writing in word processing in student reports. 


\section{Research Methodology}

This research approach uses qualitative research aims to have the potential to direct, describe and know linguistic intelligence in learning to write explanatory texts. This research was conducted in five schools in the District of Kubu Raya, West Kalimantan, in the VIII grade junior high school. The subjects of this study were eighth grade students of SMP Negeri, Kubu Raya Regency, West Kalimantan. Data collection techniques used observation, interviews, and documentation.

\section{Research Results and Discussion}

This study obtains matters related to linguistic intelligence factors that affect the students' high or low levels in writing explanatory texts. Internal factors that influence the low linguis tic intelligence of eighth grade students of SMP Negeri Kubu Raya Regency are physical conditions, emotional conditions, and learning styles. Factors that do not affect the low linguis tic intelligence are the interests and ways of teaching teachers. Linguistic intelligence is related to communication skills. Humans carry out communication by utilizing the sensory org ans, namely the ears, mouth/utterance, eyes and hands, so that the physical condition of the sensory organs will affect the linguistic intelligence of children.

Based on res earch obtained at the SMP Negeri Kubu Raya Dis trict, there are fifteen children who have low linguistic intelligence and low explanatory text writing scores from 96 students. The fifteenth factor of children is due to their vision, intelligence in processing words in writing slow texts. This physical condition that inhibits linguis tic intelligence. Factors of student conditions related to student emotions, namely the ability of students to motivate themselves and their enthusiasm. Children who have prominent linguistic intelligence will be eager to read books, like writing es says, are able to listen well and can speak well in public. Students who are excited when doing listening, speaking, reading and writing activities. The emotional condition of students who are not excited when speaking and reading can hamper their linguis tic development [4].

He results of research conducted by researchers on eighth grade students of SMP Negeri Kubu Ray a Dis trict five students tend to be shy, so that it inhibits him from expressing the terms of words contained in the explanatory text content that is read. Shame also impedes the development of thought, namely linguistic intelligence in the writing of an explanatory text. Researchers found an internal factor in Kubu Raya District Middle School students learning styles. Learning styles also affect students' linguistic intelligence. Based on research that not allstudents effectively use learning styles because students are not accustomed to independent learning by reading books. The next factor that affects students 'linguis tic intelligence in writing explanatory texts is the factor of students' interest in learning to explore their own potential.

External factors consist of ways of teaching teachers and supporting school programs. The teacher is one of the central figures and plays an important role in the development of linguistic intelligence. Teacher strategies or methods applied during the learning process will build student character as expected. This opinion is in line with the opinion of Thomas Armstrong which says teaching students must be adapted to the child's development and carrying out activities that involve listening, speaking, reading and writing activities so that students' linguistic intelligence can develop pro perly [1].

Based on the results of the study, teachers of state junior high school Kubu Raya Regency VIII Kubu Raya Regency, West Kalimantan have implemented learning that develops students' linguistic intelligence. The teacher accustoms students to listening, speaking, reading and writing activities. Students are often asked to conduct discussions and presentations in front of the class. But the development of students' linguistic intelligence remains uneven and optimal.

Some students still have less linguistic intelligence, so the way of teaching the teacher does not influence the development of linguistic intelligence. Intelligence can be developed with non-formal education. Non-formal education can be in the form of supporting programs such as debate extracurricular activities, schoolnewspapers, and language clubs. Based on research data, there are 
school programs that support those that have not been implemented to the maximum. The school has facilitated a wall magazine, but it has not been used to dis play student work [1].

\section{Conclusion}

Conclusions fromthe results of research that has been done, it can be concluded that the factors that influence the low linguistic intelligence of eighth grade students of SMP Negeri, Kubu Raya Regency, West Kalimantan, consis tof factors from within and outside of students. Factors originating from within students include physical conditions, emotional conditions, and learning styles. While factors that come fromoutside the student self are supporting school programs. External factors are also influenced by the way teachers teach and inadequate facilities.

\section{References}

[1] Armstrong, T. (2005). Every Child is Smart. Jakarta: PT Gramedia Pustaka Utama.

[2] Gardner, H. (2003). CompoundIntelligence: Theory in practice. (Subtitles: Drs. Alexander Sindoro. Batam Center: Interactional Publisher.

[3] Iskandaewassid, \& Suhendar, D. (2013). Language learning strategy. Bandung: Rosdakarya.

[4] Jasmine, J. (2012). The Method of Teaching Multiple Intelligences. Bandung: Nendendent of Cendikia.

[5] Johson, E. B. (2009). Contextual Teaching \& Learning: Making Teaching and Learning Activities Fun and Meaningful. Bandung: Mizan Learning Center (MLC).

[6] Josua, H. M. (2009). Improving explanation writing skills of Junior Secondary Learners in Life Sciences: A case study. South Africa: Rhodes University.

[7] Rohman, A. (2011). Memahami Pendidikan Dan Ilmu Pendidikan. Yogyakarta: Laks Bang Mediatama. 